\title{
Live changes in muscle glycogen concentration of steers due to feeding and fasting as determined through serial biopsies of the Longissimus dorsi muscle
}

\author{
Ariel Apaoblaza ${ }^{1}$, and Carmen Gallo ${ }^{1^{*}}$
}

\begin{abstract}
Insufficient glycogen content in bovine muscle at slaughter produces meat with high final $\mathrm{pH}(>5.8)$ which is undesirable. The objective of this study was to determine through biopsies the live changes in muscle glycogen concentration (MGC) of housed steers fed on hay or hay plus energy concentrate for $30 \mathrm{~d}$ and then determine the effect of food deprivation (fasting) for $24 \mathrm{~h}$ on the same variable. Ten steers of similar age, weight, and phenotypic characteristics were housed in individual pens and randomly assigned to two feeding treatments: ad libitum hay only $(\mathrm{H}, \mathrm{n}=5)$ and ad libitum hay plus flaked corn (Zea mays L.) ( $\mathrm{HC}, \mathrm{n}=5)$. Biopsies $(\mathrm{B})$ were taken from the Longissimus dorsi muscle at four occasions: the day before the start of experiment $\left(\mathrm{B}_{0}\right)$, after $15 \mathrm{~d}\left(\mathrm{~B}_{1}\right)$, after $30 \mathrm{~d}\left(\mathrm{~B}_{2}\right)$, and fasted for $24 \mathrm{~h}$ after $\mathrm{B}_{2}\left(\mathrm{~B}_{3}\right)$. Before each biopsy, steers were sedated with xylazine $\left(0.03 \mathrm{~mL} \mathrm{~kg}^{-1}\right)$ and lidocaine was applied locally; samples were frozen in liquid nitrogen to determine MGC. Results showed a significant $(\mathrm{P}<0.05)$ effect of diet treatment $(\mathrm{HC}>\mathrm{H})$ and also of time $\left(\mathrm{B}_{2}>\mathrm{B}_{1}\right)$ on $\mathrm{MGC}$; the decrease in MGC of steers due to fasting $\left(\mathrm{B}_{2} v s . \mathrm{B}_{3}\right)$ was not significant $(\mathrm{P}>0.05)$. It was concluded that muscle biopsies allowed to detect a difference in the increase of MGC in steers fed an energy supplementation compared to steers fed hay only, and that fasting for $24 \mathrm{~h}$ tended to reduce MGC in both groups.
\end{abstract}

Key words: Cattle, muscle biopsies, muscle glycogen.

\section{INTRODUCTION}

Insufficient glycogen content in bovine muscle at slaughter decreases the availability of glucose that serves as a substrate for the action of the glycolytic enzymes, producing less lactic acid in the postmortem muscle; therefore, the resulting meat presents a high $\mathrm{pH}(>5.8)$, high water retention capacity and an unattractive dark color, a problem known as dark cutting or DFD (dark, firm, and dry) (McVeigh and Tarrant, 1982). Fasting, transportation, herding and social regrouping of unknown bovines, as well as many other stress triggers occurring during stages prior to slaughter can lower muscle glycogen concentration in cattle (Gallo, 2004; Ferguson and Warner, 2008). The darker color of meat, its increased water retention capacity, and high $\mathrm{pH}$ have a negative effect on meat quality, its trade in the domestic market and especially for the export market, because the high $\mathrm{pH}$ decreases shelf life of meat due to a higher predisposition to the attack by microorganisms (Hofmann, 1988).

It has been reported that the energy supply for at least 2 wk prior to transport of cattle to slaughter increases muscle glycogen concentration (Immonen et al., 2000)

${ }^{1}$ Universidad Austral de Chile, Facultad de Ciencias Veterinarias, Casilla 567 Valdivia, Chile.

*Corresponding author (cgallo@uach.cl).

Received: 13 July 2013.

Accepted: 9 January 2014.

doi:10.4067/S0718-58392014000100009 and can mitigate the effects of chronic stress on $\mathrm{pH}$ (Knee et al., 2007; Gallo et al., 2013). Measuring muscle glycogen concentration in cattle by using muscle biopsies allows to determine variations of glycogen in the same animal over time (Pethick et al., 1994; Immonen et al., 2000); for example, if an animal receives different levels of energy intake through food, it can be determined if this contribution increases its muscle glycogen concentration; if these animals are subsequently subjected to different stressors, it is possible to measure the incidence that these have on the muscle glycogen concentration and to assess the risk involved by each one of them. It has been reported that physical exercise or environmental stressors reduce muscle glycogen in steers from 77 to $50 \mathrm{mmol}$ $\mathrm{kg}^{-1}(35 \%)$, while the recovery of glycogen concentration

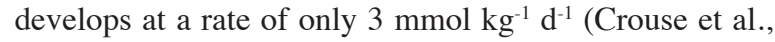
1984). McVeigh and Tarrant (1982) found that glycogen recovery after a treatment with adrenalin depended on the energy supplied previously; with a barley-based diet the

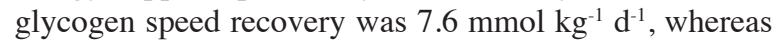
a hay-based diet showed a recovery speed of $6.1 \mathrm{mmol}$ $\mathrm{kg}^{-1} \mathrm{~d}^{-1}$, and fasted animals reported only $1.5 \mathrm{mmol} \mathrm{kg} \mathrm{kg}^{-1}$ $\mathrm{d}^{-1}$. Same authors concluded that the recovery rate of muscle glycogen is influenced by the type of diet and that a low recovery rate may be caused by a low amount of available glucose, especially in fasted animals. Immonen et al. (2000) reported that the decrease in muscle glycogen concentration in cattle treated with adrenaline depends on previous feeding of animals; they found that cattle 
that had previously been fed energy food had a muscle glycogen decrease of $8 \mathrm{mmol} \mathrm{kg}^{-1}$, while the decrease was $46 \mathrm{mmol} \mathrm{kg}^{-1}$ in cattle under a low energy input.

In Chile, there have been several studies on the high $\mathrm{pH}$ problem in cattle (Hargreaves et al., 2003; Gallo, 2004; Amtmann et al., 2006). Some of them have reported the effect of energy supplementation on $\mathrm{pH}$ and postmortem muscle glycogen in steers (Gallo et al., 2013), others have determined the effects of different transport times and fasting on the same variable (Gallo and Lizondo, 2000; Gallo et al., 2003, Herrera and Gallo, 2009). However, it has not been demonstrated yet the extent of increase or decrease of in vivo muscle glycogen caused by each of these factors in particular, which is possible to achieve through serial biopsies. Since the high $\mathrm{pH}$ is an important problem in Chile (Hargreaves et al., 2003; Gallo, 2004) and causes significant economic losses to the meat industry (Vidal et al., 2009; Leyva-García et al., 2012), the objective of this study was to determine through biopsies the live changes in the concentration of muscle glycogen of housed steers fed on hay alone or hay plus an energy concentrate for $30 \mathrm{~d}$ and then determine the effect of food deprivation (fasting) for $24 \mathrm{~h}$ on the same variable.

\section{MATERIALS AND METHODS}

Ten steers, approximately 1-yr old, were used. The animals were bought from a livestock market for the experiment and presented similar phenotypic characteristics and body condition; they were 'Friesian' $\times$ 'Red Angus' ('Clavel') with an average weight of $341 \pm 18.7 \mathrm{~kg}$. The steers, previously fed with pasture only, were housed individually in pens of approximately $9 \mathrm{~m}^{2}$; they were weighed and allocated in blocks to two treatments according to weight. One treatment consisted of ad libitum hay-based diet only (H) and the other was ad libitum hay plus an amount of steam flaked corn $(\mathrm{HC})$; the latter was equal to $1 \%$ of their live weight, for $30 \mathrm{~d}$. The flaked corn (88\% DM, $1.12 \%$ ash, $6 \%$ crude protein, and $2.65 \mathrm{Mcal} \mathrm{kg}^{-1}$ ) was given in a single daily ration, and hay $(88.2 \% \mathrm{DM}, 6.9 \%$ ash, $11.9 \%$ crude protein, $1.87 \mathrm{Mcal} \mathrm{kg}^{-1}$ gross energy, and $50.3 \%$ $\mathrm{NDF}$ ) was offered three times a day. Steers were weighed the day before the start of the experiment $\left(\mathrm{B}_{0}\right)$, at $15 \mathrm{~d}$ $\left(\mathrm{B}_{1}\right)$, and at $30 \mathrm{~d}\left(\mathrm{~B}_{2}\right)$ to determine the daily weight gain; total DM consumed (DM kg-1) and energy intake per day (Mcal kg-1 $\mathrm{d}^{-1}$ ) were determined.

Muscle biopsies from all the steers were obtained at $\mathrm{B}_{0}, \mathrm{~B}_{1}, \mathrm{~B}_{2}$, and $24 \mathrm{~h}$ after food deprivation after $\mathrm{B}_{2}$ $\left(B_{3}\right)$. Biopsies were obtained by sedating each steer with xylazine $0.03 \mathrm{~mL} \mathrm{~kg}^{-1}$ body weight, and then $3 \mathrm{~mL}$ subcutaneous and $3 \mathrm{~mL}$ intramuscular lidocaine were applied on the biopsy site. Samples of about $1 \mathrm{~g}$ muscle tissue were obtained from Longissimus dorsi muscle at the level of L1 and L2, as this location is easy to find behind the last rib, according to the protocol established by Pethick et al. (1994). Samples were identified, placed in cryovials, and immediately frozen in liquid nitrogen at $-80{ }^{\circ} \mathrm{C}$ until analysis. The method for determining muscle glycogen concentration (MGC) was based on that described by Chan and Exton (1976), which involves purification and enzymatic digestion of samples. Samples were first grounded in liquid nitrogen and $100 \mathrm{mg}$ tissue were mixed with $400 \mu \mathrm{L} 30 \% \mathrm{KOH}$ and incubated for 15 min at $100{ }^{\circ} \mathrm{C}$. Filter paper (cellulose chromatography paper Whatman 31ET) was cut in pieces of $2 \times 2 \mathrm{~cm}$, and a known volume of each sample was poured on the paper $(50 \mu \mathrm{L})$. At the same time 15,30 , and $75 \mu \mathrm{L}$ standard sample (glycogen solution $0.8 \mathrm{mg} \mathrm{mL}^{-1}$ ) and 15 $\mu \mathrm{L}$ distilled water were added in duplicate on filter papers, each paper was then placed in a glass tube and left to dry. Subsequently, $5 \mathrm{~mL}$ of $66 \%$ ethanol $\left(-20^{\circ} \mathrm{C}\right)$ were added and papers were dried in an oven at $40{ }^{\circ} \mathrm{C}$. A volume of 1 $\mathrm{mL}$ of amyloglucosidase solution $0.5 \mathrm{mg} \mathrm{mL}^{-1}$ was added in $400 \mathrm{mM}$ sodium acetate buffer $\mathrm{pH} 4.8$ and the solution was incubated $2 \mathrm{~h}$ at $37^{\circ} \mathrm{C}$. A sample for the determination of glucose (Glucose PAP kit) was taken from each tube. After enzymatic oxidation in presence of glucose oxidase, the hydrogen peroxide formed reacts under the catalysis of peroxidase with phenol and 4-aminophenazone forming a red-violet complex. Calibration curves were performed for the calculations of glucose and glycogen, which is expressed in mmol kg-1.

The statistical analyses were carried out using CORR, GLM, and MIXED procedures of SAS (SAS Institute, 2011). Pearson correlations between MGC and average daily weight gain for $\mathrm{B}_{1}$ (period $\mathrm{B}_{0}-\mathrm{B}_{1}$ ) and for $\mathrm{B}_{2}$ (period $\mathrm{B}_{1}-\mathrm{B}_{2}$ ) and between MGC and metabolizable energy intake (only $\mathrm{B}_{2}$ ) were estimated within each diet treatment. For time $\mathrm{B}_{0}$ a one way ANOVA was used to evaluate the differences between treatments $(\mathrm{HC} v s . \mathrm{H})$. A repeated measures design was used to detect differences between treatments $(\mathrm{HC} v s . \mathrm{H})$ and between measurements in time $\mathrm{B}_{1}$ and $\mathrm{B}_{2}$. In the last period $\left(\mathrm{B}_{3}\right)$, two way ANOVA were applied on MGC and muscle glycogen change between $\mathrm{B}_{2}$ and $\mathrm{B}_{3}$. Shapiro-Wilk test for normality was applied on the residual of MIXED and GLM procedures.

\section{RESULTS AND DISCUSSION}

The use of muscle biopsies allowed to observe changes in MGC produced in the same animal at different times and under different feeding treatments. To date, no studies have been carried out in Chile using muscle biopsies to determine live MGC and the MGC values that had been previously reported came from postmortem muscle (Gallo and Lizondo, 2000; Mencarini, 2002; Hargreaves et al., 2003). Although muscle biopsies were relatively simple to perform, the procedure seems useful only as a research technique and would not apply in commercial practice because it causes some minor damage to the tissue and also it would leave some residues, which would affect quality of the carcass and meat in the invaded zone, when 
performing the procedure shortly before sending animals to slaughter.

Table 1 shows that supplementation of steers with flaked corn as used in this study during $30 \mathrm{~d}$ did not cause significant changes in terms of daily weight gain due to diet treatment or time. MGC was similar at $\mathrm{B}_{0}$, however there was a significant effect on MGC due to treatment $(\mathrm{HC}>\mathrm{H}, \mathrm{P}<0.05)$ and time $\left(\mathrm{B}_{2}>\mathrm{B}_{1}\right)($ Table 2). No interaction between both factors was found. This different response in MGC would be caused by the metabolizable energy intake of HC steers, which was higher than that of $\mathrm{H}$ steers (Table 1). These results are similar to those of Immonen et al. (2000), who reported that increasing 2.5 times energy provided in the diet produces an increase from 14 to $49 \mathrm{mmol} \mathrm{kg}^{-1}$ in MGC. Correlation found between MGC and metabolizable energy intake $(r=0.61$ in $\mathrm{HC}$ and $\mathrm{r}=-0.11$ in $\mathrm{H}$ at $\mathrm{B}_{2}$ ) and between MGC and weight gain $(r=-0.57$ and 0.57 in $\mathrm{HC}$, and $r=0.25$ and -0.69 in $\mathrm{H}$, at $\mathrm{B}_{1}$ and $\mathrm{B}_{2}$ respectively), were not significant $(\mathrm{r}=0$ with $\mathrm{P}>0.05)$.

The muscle biopsies to L. dorsi muscle in this study showed high variability in MGC between individuals (Table 2), registering a maximum concentration of 82.72 mmol kg-1 and a minimum of $9.76 \mathrm{mmol} \mathrm{kg}^{-1}$. In general, these samples obtained from field biopsies, without transportation, fasting nor antemortem handling, allowed to observe an average MGC of 59.46 and $49.44 \mathrm{mmol}$ $\mathrm{kg}^{-1}$, respectively, which are both higher (Table 2) than those previously found in steers immediately postmortem at the slaughterhouse. Gallo and Lizondo (2000) found in L. dorsi of steers immediately after slaughter (30 min), a

Table 1. Means and standard deviations (SD) of initial live weights, weight gains at $15 \mathrm{~d}\left(\mathrm{~B}_{1}\right)$ and at $30 \mathrm{~d}\left(\mathrm{~B}_{2}\right)$ and daily metabolizable energy (ME) consumed by steers fed hay $(\mathrm{H})$ or hay plus concentrate (HC).

\begin{tabular}{|c|c|c|}
\hline & $\begin{array}{c}\mathrm{HC} \\
(\text { Mean } \pm \text { SD })\end{array}$ & $\begin{array}{c}\mathrm{H} \\
(\text { Mean } \pm \mathrm{SD})\end{array}$ \\
\hline Initial live weight, $\mathrm{kg}$ & $339.2 \pm 17.3$ & $343.2 \pm 21.8$ \\
\hline $\mathrm{B}_{1}$ Weight gain, $\mathrm{kg} \mathrm{d}^{-1}$ & $1.08 \pm 1.01$ & $0.75 \pm 0.36$ \\
\hline $\mathrm{B}_{2}$ Weight gain, $\mathrm{kg} \mathrm{d}^{-1}$ & $0.89 \pm 0.96$ & $0.47 \pm 0.67$ \\
\hline $\mathrm{B}_{2}$ ME intake, Mcal kg-1 $\mathrm{d}^{-1}$ & $507.6 \pm 28.9$ & $432.4 \pm 7.2$ \\
\hline
\end{tabular}

Table 2. Arithmetic and least squares means and standard deviations (SD) of muscle glycogen concentrations in Longissimus dorsi biopsies of steers fed hay $(\mathrm{H})$ or hay plus concentrate $(\mathrm{HC})$.

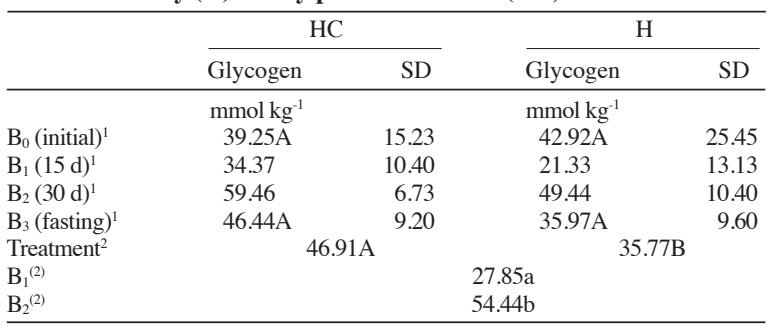

${ }^{1}$ Arithmetic means.

${ }^{2}$ Least squares means obtained by repeated measures analysis.

Different capital letters mean significant differences between treatments $(\mathrm{P}<0.05)$.

Different lower-case letters mean significant differences between periods $(\mathrm{P}<0.05)$. mean MGC of $23.6 \mathrm{mmol} \mathrm{kg}^{-1}$ after 3-h transport and 17.6 mmol kg-1 after 16-h transport; in this study it was also observed that MGC decreased when animals spent more time in lairage prior to slaughter. Results of the present study also confirm that fasting for $24 \mathrm{~h}$ reduces muscular glycogen (Table 2).

Daly et al. (1999) demonstrated that providing steers with more energy in their diet (corn based) caused a $20 \%$ increase in MGC compared to animals fed pasture only. Mencarini (2002) found in L. dorsi of steers that had a pH $>5.8$ at $24 \mathrm{~h}$ postmortem, a MGC of $7.36 \mathrm{mmol} \mathrm{kg}^{-1}$ at slaughter while those with $\mathrm{pH}<5.8$ had $36.5 \mathrm{mmol} \mathrm{\textrm {kg } ^ { - 1 }}$. Gallo et al. (2013) found a mean of $30.6 \mathrm{mmol} \mathrm{kg} \mathrm{kg}^{-1}$ of postmortem glycogen in Semimembranosus muscle.

After being subjected to food deprivation for $24 \mathrm{~h}\left(\mathrm{~B}_{3}\right)$, steers from both treatments tended to decrease their MGC $(\mathrm{P}>0.05)$. These results demonstrate that steers had to resort to using their energy reserve due to being deprived of food; additionally, food deprivation itself can also be a stressor. Pethick et al. (1994) found a decrease of 20 mmol kg-1 of muscle glycogen in animals fasted for $18 \mathrm{~h}$ at the slaughterhouse and this decrease reached $30 \%$ to $40 \%$ depending on the muscle. Probably due to the high variability between individuals and the low number of animals used in this study no significant changes were found (Table 2). However it should be noted that there was a 22\% decrease in MGC in HC steers whereas there was a $27 \%$ decrease in those fed hay only, which could indicate a certain protective effect of the increased energy intake when facing deprivation of food and/or stress. This is consistent with previous reports of Gallo et al. (2013), who showed that in steers on pasture, energy supplementation with flaked corn for 4 wk prior to slaughter, could reduce the presentation of high $\mathrm{pH}$ and postmortem dark cutting and also reduced variability of MGC in these animals when compared to non-supplemented animals, although MGC (measured postmortem) was not significantly different from control steers fed pasture only. In this sense, McVeigh and Tarrant (1982) also found that after a treatment with adrenaline (simulated stress) MGC decreased by $25 \%, 27 \%, 38 \%$ in animals previously fed barley, hay, and fasted, respectively. Moreover, Immonen et al. (2000) observed in animals with and without prior energy supply, a decrease in MGC of 8 and $40 \mathrm{mmol} \mathrm{kg}{ }^{-1}$, respectively, when treated with adrenaline.

An important aspect to consider is that a change in feeding and housing can lead to an initial decrease in MGC, due to the stress associated with these changes (Table 2). The initial muscle glycogen decrease observed between samples $\mathrm{B}_{0}$ and $\mathrm{B}_{1}$ had also been recorded by Knee et al. (2007), who found that moving cattle from pasture grazing to being housed caused a decrease of $30 \%$ MGC the first week of assay. Both the change in diet and the stress of changing from pasture to housing system, and in this case probably the very act of taking muscle biopsies, could explain the initial decrease of MGC in 
steers of both treatments. This is an important factor to consider when planning a strategy for supplementation of steers before sending them to slaughter, because it must consider a period of adaptation of animals to the new diet (and/or environment) before achieving an increase of muscle glycogen that can in turn protect from the stress prior to slaughter and reduce high $\mathrm{pH}$ problems. Further studies should be carried out with a larger number of animals and up to slaughter, in order to test how preslaughter operations, like transport and fasting in a different environment (slaughterhouse), affect MGC and how this is related to carcass $\mathrm{pH}$.

\section{CONCLUSIONS}

Even though results are preliminary due to the low number of animals used, muscle biopsies allowed detecting a difference in the increase of muscle glycogen concentration (MGC) in steers fed an energy supplementation compared to steers fed hay only, and that fasting for $24 \mathrm{~h}$ tended to reduce MGC in both groups.

\section{ACKNOWLEDGEMENTS}

The authors wish to thank project FONDECYT 1120757 for financing this study and Dr. Juan Pablo Smulders for his support with the statistical analysis of data.

\section{LITERATURE CITED}

Amtmann, V.A., C. Gallo, G. van Schaik, y N. Tadich. 2006. Relaciones entre el manejo antemortem, variables sanguíneas indicadoras de estrés y $\mathrm{pH}$ de la canal en novillos. Archivos de Medicina Veterinaria 38:259-264.

Chan, T.M., and J.H.Exton. 1976.Arapid method for the determination of glycogen content and radioactivity in small quantities of tissue or isolated hepatocytes. Analytical Biochemistry 71:96-105.

Crouse, J.D., S.B. Smith, and R.L. Prior. 1984. Bovine muscle glycogen as affected by fasting and refeeding. Journal of Animal Science 59:384-387.

Daly, C.C., O.A. Young, A.E. Graafhuis, S.M. Moorhead, and H.S. Easton. 1999. Some effects of diet on beef meat and fat attributes. New Zealand Journal of Agricultural Research 42:279-287.

Ferguson, D.M., and R.D. Warner. 2008. Have we underestimated the impact of preslaughter stress on meat quality in ruminants? Meat Science 80:12-19.

Gallo, C. 2004. Carnes de corte oscuro en bovinos (Dark cutting beef). Revista Americarne para América Latina y El Caribe (Spanish-English) 41:10-13.

Gallo, C., A. Apaoblaza, R.G. Pulido, y N. Jerez-Timaure. 2013. Efectos de una suplementación energética en base a maíz roleado sobre las características de calidad de la canal y la incidencia de corte oscuro en novillos. Archivos de Medicina Veterinaria 45:237-245.

Gallo, C., y G. Lizondo. 2000. Efectos de diferentes tiempos de ayuno antes del sacrificio sobre el contenido de glicógeno muscular y hepático y el $\mathrm{pH}$ final de la canal en novillos. XI Congreso Nacional de Medicina Veterinaria, Santiago. 25-27 octubre. Universidad de Chile, Facultad de Ciencias Veterinarias y Pecuarias, Santiago, Chile.

Gallo, C., G. Lizondo, and T. Knowles. 2003. Effects of journey and lairage time on steers transported to slaughter in Chile. Veterinary Record 152:361-364.
Hargreaves, A., L. Barrales, R. Larraín, y L. Zamorano. 2003. Factores que influyen en el $\mathrm{pH}$ último e incidencia de corte oscuro en canales de bovino. Ciencia e Investigación Agraria 3:155-166.

Herrera, C., y C. Gallo. 2009. Análisis descriptivo de la presentación de canales con $\mathrm{pH}$ elevado en bovinos de distinta procedencia geográfica y tiempo de espera prefaena. p. 270-271. Resúmenes XXXIV Congreso Anual de la Sociedad Chilena de Producción Animal (SOCHIPA), Pucón. 21-23 octubre. SOCHIPA, Temuco, Chile.

Hofmann, K. 1988. El pH, una característica de la calidad de la carne. Fleischwirtschaft (Spanish) 2:13-18.

Immonen, K., M. Ruusunen, K. Hissa, and E. Puolanne. 2000. Bovine muscle glycogen concentration in relation to finishing diet, slaughter and ultimate $\mathrm{pH}$. Meat Science 55:25-31.

Knee, B.W., L.J. Cumins, P.J. Walker, G.A. Kearney, and R.D Warner. 2007. Reducing dark-cutting in pasture-fed beef stress by high-energy supplementation. Australian Journal of Experimental Agriculture 47:1277-1283.

Leyva-García, I.A., F. Figueroa-Saavedra, E. Sánchez-López, C. Pérez-Linares, y A. Barreras-Serrano. 2012. Impacto económico de la presencia de carne DFD en una planta de sacrificio Tipo Inspección Federal (TIF). Archivos de Medicina Veterinaria 44:39-42

Mencarini, I. 2002. Efectos de dos densidades de carga y dos tiempos de transporte sobre el contenido de glucógeno hepático y muscular, $\mathrm{pH}$ y color de la carne. Memoria de título. Universidad Austral de Chile, Facultad de Ciencias Veterinarias, Valdivia, Chile.

McVeigh, J.M., and P.V. Tarrant. 1982. Glycogen content and repletion rates in beef muscle, effects of feeding and fasting. Journal of Nutrition 112:1306-1314.

Pethick, D.W., J.B. Rowe, and B.L. McIntyre. 1994. Effect of diet and exercise on glycogen levels in the muscle of cattle. Proceedings of the Australian Society of Animal Production 20:403.

SAS Institute. 2011. SAS ${ }^{\circledR} 9.3$ Guide to software updates. SAS Institute, Cary, North Carolina, USA.

Vidal, R., C. Ferrando, A. Köpfer, y C Almuna. 2009. Pérdidas económicas ocasionadas por corte oscuro en ganado bovino. $\mathrm{p}$. 242-243. Resúmenes de la XXXIV Reunión Anual de la Sociedad Chilena de Producción Animal (SOCHIPA), Pucón. 21-23 octubre. SOCHIPA, Temuco, Chile. 